\title{
FOXP1 wt Allele
}

National Cancer Institute

\section{Source}

National Cancer Institute. FOXP1 wt Allele. NCI Thesaurus. Code C97550.

Human FOXP1 wild-type allele is located in the vicinity of 3p14.1 and is approximately 629

$\mathrm{kb}$ in length. This allele, which encodes forkhead box protein P1, plays a role in the

negative regulation of transcription. Mutation of the gene is associated with mental

retardation with language impairment and autistic features. A translocation $\mathrm{t}(9 ; 3)$

(p13;p14.1) of this gene with the PAX5 gene is associated with acute lymphoblastic leukemia. 